\title{
The Effects of Crystal Phase and Particle Morphology of Calcium Phosphates on Proliferation and Differentiation of Human Mesenchymal Stromal Cells
}

Citation for published version (APA):

Danoux, C., Pereira, D., Dobelin, N., Stahli, C., Barralet, J., van Blitterswijk, C., \& Habibovic, P. (2016). The Effects of Crystal Phase and Particle Morphology of Calcium Phosphates on Proliferation and Differentiation of Human Mesenchymal Stromal Cells. Advanced Healthcare Materials, 5(14), 1775-1785. https://doi.org/10.1002/adhm.201600184

Document status and date:

Published: 20/07/2016

DOI:

10.1002/adhm.201600184

Document Version:

Publisher's PDF, also known as Version of record

Document license:

Taverne

Please check the document version of this publication:

- A submitted manuscript is the version of the article upon submission and before peer-review. There can be important differences between the submitted version and the official published version of record.

People interested in the research are advised to contact the author for the final version of the publication, or visit the DOI to the publisher's website.

- The final author version and the galley proof are versions of the publication after peer review.

- The final published version features the final layout of the paper including the volume, issue and page numbers.

Link to publication

\footnotetext{
General rights rights.

- You may freely distribute the URL identifying the publication in the public portal. please follow below link for the End User Agreement:

www.umlib.nl/taverne-license

Take down policy

If you believe that this document breaches copyright please contact us at:

repository@maastrichtuniversity.nl

providing details and we will investigate your claim.
}

Copyright and moral rights for the publications made accessible in the public portal are retained by the authors and/or other copyright owners and it is a condition of accessing publications that users recognise and abide by the legal requirements associated with these

- Users may download and print one copy of any publication from the public portal for the purpose of private study or research.

- You may not further distribute the material or use it for any profit-making activity or commercial gain

If the publication is distributed under the terms of Article $25 \mathrm{fa}$ of the Dutch Copyright Act, indicated by the "Taverne" license above, 


\title{
The Effects of Crystal Phase and Particle Morphology of Calcium Phosphates on Proliferation and Differentiation of Human Mesenchymal Stromal Cells
}

\author{
Charlène Danoux, Daniel Pereira, Nicola Döbelin, Christoph Stähli, Jake Barralet, \\ Clemens van Blitterswijk, and Pamela Habibovic**
}

Calcium phosphate ( $\mathrm{CaP}$ ) ceramics are extensively used for bone regeneration; however, their clinical performance is still considered inferior to that of patient's own bone. To improve the performance of CaP bone graft substitutes, it is important to understand the effects of their individual properties on a biological response. The aim of this study is to investigate the effects of the crystal phase and particle morphology on the behavior of human mesenchymal stromal cells (hMSCs). To study the effect of the crystal phase, brushite, monetite, and octacalcium phosphate (OCP) are produced by controlling the precipitation conditions. Brushite and monetite are produced as plate-shaped and as needle-shaped particles, to further investigate the effect of particle morphology. Proliferation of hMSCs is inhibited on ОСР as compared to brushite and monetite in either morphology. Brushite needles consistently show the lowest expression of most osteogenic markers, whereas the expression on OCP is in general high. There is a trend toward a higher expression of the osteogenic markers on plate-shaped than on needle-shaped particles for both brushite and monetite. Within the limits of $\mathrm{CaP}$ precipitation, these data indicate the effect of both crystal phase and particle morphology of $\mathrm{CaPs}$ on the behavior of hMSCs.

\section{Introduction}

Synthetic biomaterials are becoming increasingly important in the field of regenerative medicine as they offer a relatively inexpensive and readily available alternative to patient's own tissue, and to strategies based on cells or growth factors. To fulfill this role successfully, synthetic biomaterials are expected to play an active role in the very dynamic process of regeneration of damaged tissue or organ. For this, a different set of properties is required as compared to conventional permanent medical devices such as total hip implants. ${ }^{[1]}$ Furthermore, a full understanding of the effects of individual properties of a biomaterial on a biological response is of utmost importance.

Some biomaterials allow a relatively close control over a single parameter while keeping the others constant, which is needed for the in-depth study of the biological effects of such a parameter. For example, mechanical properties such as the stiffness of a hydrogel can be tuned in a relatively facile manner by varying the crosslinking density of the network. ${ }^{[2]}$ Similarly, topography of the polymeric surfaces can be controlled down to the nanoscale using a diversity of techniques, including nanolithography-based ones. ${ }^{[3]}$

In contrast to a large number of polymers, the properties of inorganic biomaterials, in particular ceramic materials, are normally a result of a processing route and cannot be considered truly designed. Calcium phosphate $(\mathrm{CaP})$ ceramics are among the most extensively used biomaterials in hard skeletal tissue regeneration, ${ }^{[4]}$ in the form of (bulk) ceramic particles, pre-shaped fillers, injectables, or as coatings on other materials. Regardless of the production method, i.e., precipitation, sol-gel or sintering, the end product is usually a crystalline material with distinct $\mathrm{CaP}$ composition, crystallinity, crystal size, surface roughness, specific surface area, etc. ${ }^{[5]}$ CaPs are generally considered to play a structural role in bone regeneration, acting as a barrier to soft tissue infiltration and as facilitators of the onset and growth of new bone tissue. On the other hand, all CaP-based compounds are, to different extents, degradable in the physiological environment. However, no conclusive evidence exists yet for the fact that free calcium $\left(\mathrm{Ca}^{2+}\right)$ or inorganic

DOI: 10.1002/adhm.201600184 
Brushite needles
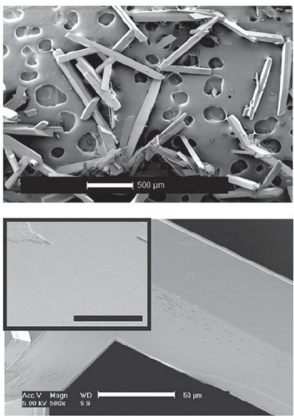

Surface area $\left(\mathrm{m}^{2} / \mathrm{g}\right)$
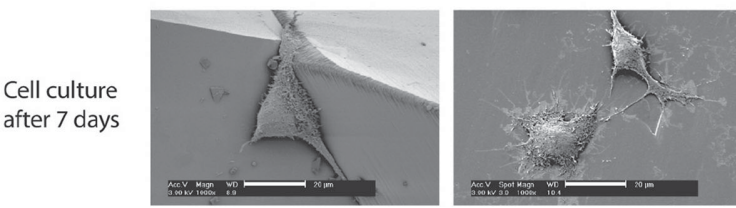

Monetite needles

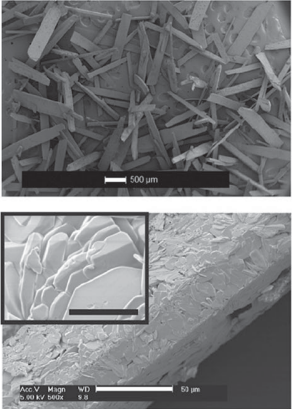

$2.69 \pm 0.02$
Monetite plates

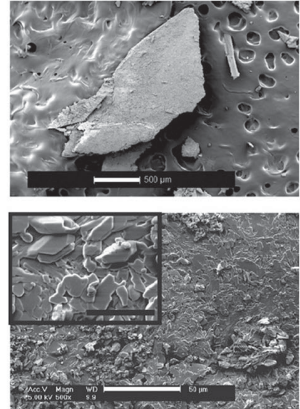

$2.94 \pm 0.02$
OCP

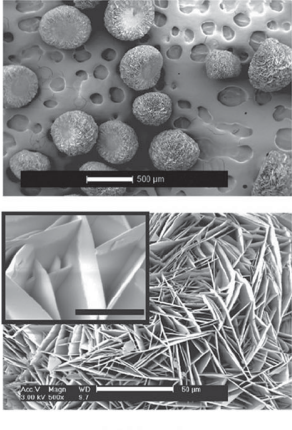

$6.65 \pm 0.02$

Figure 1. SEM images at low (first row) and high (second row) magnification and specific surface area of BN, BP, MN, MP, and OCP, and SEM images of cells after $7 \mathrm{~d}$ of culture on these CaPs in basic medium (last row) (scale bars 500, 50, and $20 \mu \mathrm{m}$, scale bar insets $10 \mu \mathrm{m}$ ).

phosphate $\left(\mathrm{P}_{\mathrm{i}}\right)$ ions released from these materials play a direct role in the biological responses to these materials. ${ }^{[6]}$ This is in a part because the process of dissolution/reprecipitation of a ceramic is not dependent on one, but on a multitude of material characteristics, including CaP crystal phase and specific surface area. Furthermore, it is extremely difficult to modify one property of a ceramic without affecting the others through conventional production techniques.

In our recent work, we have presented a concept in which various techniques were combined to decouple the effect of the presence of $\mathrm{CaP}$ from the (surface) structural properties of $\mathrm{CaP}$ materials. ${ }^{[7]}$ We have furthermore shown that both $\mathrm{Ca}^{2+}$ and $\mathrm{P}_{\mathrm{i}}$ ions individually have the potential to stimulate osteogenesis in vitro and in vivo. ${ }^{[8]}$

Here, we employed the process of precipitation to produce CaP crystals with finely controlled crystal phase and particle morphology. We synthesized octacalcium phosphate (OCP), dicalcium phosphate dihydrate (DCPD, brushite), and dicalcium phosphate anhydrous (DCPA, monetite). Both brushite and monetite were precipitated as needle- (BN and $\mathrm{MN})$ and as plate-shaped particles (BP and MP), to investigate the effect of the particle morphology, while keeping the same crystal phase. OCP was added as $\mathrm{CaP}$ phase with a different $\mathrm{Ca} / \mathrm{P}$ ratio, although it was not possible to precipitate OCP particles with the same morphology as that of brushite and monetite.

The crystal structure of brushite consists of chains of $\mathrm{CaPO}_{4}$, arranged parallel to each other with lattice water molecules interlayerd between these chains. Monetite lacks the water inclusion and is therefore less soluble $\left(K_{\text {SODCPA }}=9.2 \times 10^{-7}\right.$ $\left.\left(\mathrm{mol} \mathrm{L}^{-1}\right)^{2}\right)$ than brushite $\left(\left(K_{\text {SODCPD }}=1.87 \times 10^{-7}\left(\mathrm{~mol} \mathrm{~L}^{-1}\right)^{2}\right) \cdot{ }^{[9]}\right.$ Brushite has been shown to occur as an intermediate phase during bone mineralization and dissolution of enamel in acids, while monetite occurs in fracture callus as well as in normal bone. ${ }^{[10]}$ Both brushite and monetite are used as cements in orthopedic and craniofacial surgery as well as drug delivery vehicles and biosensors. ${ }^{[11]}$ OCP has a layered structure involving apatitic and hydrated layers, with, in the apatitic layer, a $\mathrm{Ca}^{2+}$ and $\mathrm{P}_{\mathrm{i}}$ ions distribution similar to that in hydroxyapatite, while the hydrated layer contains lattice water and less densely packed $\mathrm{Ca}^{2+}$ and $\mathrm{P}_{\mathrm{i}}$ ions. The water content of OCP is about one fifth of that of DCPD, which explains its lower theoretical solubility $\left(K_{\mathrm{SOOCP}}=2.5 \times 10^{-99}\left(\mathrm{~mol} \mathrm{~L}^{-1}\right)^{8}\right) \cdot{ }^{[9]} \mathrm{OCP}$ is suggested to be a precursor of bone and tooth apatite crystals ${ }^{[12]}$ and to be involved in initial intramembranous bone formation. ${ }^{[13]}$ Synthetic OCP has been used as source material for bone graft substitutes in various forms including cements and thin coatings on metallic or polymeric substrates. ${ }^{[14]}$

To study the effects of crystal phase and particle morphology, clinically relevant human mesenchymal stromal cells (hMSCs) were cultured on the five CaPs, followed by an assessment of proliferation and osteogenic differentiation. The materials were thoroughly characterized before and during cell culture.

\section{Results}

\subsection{Material Characterization}

Upon preparation, the five CaPs, MN, MP, BN, BP, and OCP were characterized for their morphology and physico-chemical properties. Low magnification scanning electron microscopy (SEM) images (Figure 1, first row) showed that needle-shaped particles had an elongated 3D geometry with a length of about $1 \mathrm{~mm}$. Width and height ranged from 40 to $80 \mu \mathrm{m}$ for both phases. On the other hand, plate-shaped particles exhibited a relatively large area (about $2.5 \times 1 \mathrm{~mm}^{2}$ for $\mathrm{BP}$, and $2 \times 1 \mathrm{~mm}^{2}$ for MP), but a limited thickness, in both cases below $50 \mu \mathrm{m}$. OCP particles possessed a spherical shape with plate-like crystals radiating from the nucleus having a diameter of around $450 \mu \mathrm{m}$. 
Higher magnification SEM micrographs (Figure 1, second row), exhibited a relatively smooth surface of as-prepared $\mathrm{BN}$ and $\mathrm{BP}$ particles. In comparison to brushite, the as-prepared monetite particles showed a rougher surface. OCP particles, with plate-like crystals oriented perpendicular to the surface, appeared roughest among all CaPs prepared. Quantification of the specific surface area (Figure 1) confirmed this qualitative observation.

Polarized light microscopy analysis (Figure S1, Supporting Information) showed that BN and BP were single crystals and that their length was over $1 \mathrm{~mm}$, with minimum amount of intergrowth. In cross-polarized light they showed perfect extinction throughout the macroscopic crystals and coherent interference colors, proving the absence of aggregates and twinning. $\mathrm{MN}$ and MP, on the other hand, were polycrystalline aggregates. Revolving the samples under cross-polarized light did not cause any distinct change in interference color or extinction. Despite the random arrangement of crystallites, MN and MP exhibited pseudo-idiomorphic crystal faces, possibly originating from large brushite single-crystals formed in early stages of the synthesis, followed by a transformation to monetite polycrystals while preserving the particle shape. The shells were clearly different in architecture, finer grained and/or aligned, than the cores of the particles. OCP particles were indeed polycrystalline spherical aggregates with crystallites growing radial from the core.

The Fourier transform infrared (FTIR) spectra of BN and $\mathrm{BP}$, displayed in Figure 2A, were similar, confirming identical chemistry of both morphologies of brushite particles. Brushite spectra exhibited peaks characteristic of tetrahedral $\mathrm{PO}_{4}{ }^{3-}$ units at 526, 576, and $668 \mathrm{~cm}^{-1}(\mathrm{O}-\mathrm{P}-\mathrm{O}$ bending modes), $986 \mathrm{~cm}^{-1}$ (P-O symmetric stretching mode) and 1060, 1136, and
$1218 \mathrm{~cm}^{-1}$ (P-O asymmetric stretching modes). The presence of water in the crystal lattices was demonstrated by the peaks at $1650 \mathrm{~cm}^{-1}$ (H-O-H bending mode of water) and at 3488 and $3544 \mathrm{~cm}^{-1}$ (O-H stretching). ${ }^{[15]}$ Similar to brushite, resemblance of FTIR spectra of MN and MP indicated that both particle morphologies were of the same phase. The peaks of tetrahedral $\mathrm{PO}_{4}{ }^{3-}$ units were observed at 526 and $564 \mathrm{~cm}^{-1}$ (bending modes) and 1120 and $1068 \mathrm{~cm}^{-1}$ (stretching modes). Furthermore, the absence of a peak at around 3500 and $1650 \mathrm{~cm}^{-1}$ confirmed the anhydrous nature of the monetite particles. ${ }^{[16]}$ The FTIR spectrum of OCP exhibited two typical peaks at 860 and $912 \mathrm{~cm}^{-1}$ that can be assigned to $\mathrm{HPO}_{4}{ }^{2-}$ units in the crystal structure. ${ }^{[17]}$

The $x$-ray diffraction (XRD) raw data scans are shown in Figure 2B. The signal-to-noise ratio was acceptable and satisfactory goodness of fit was reached with Rietveld refinements (Figure S2, Supporting Information). Refinement results, including phase composition, unit cell parameters, and anisotropic crystallite sizes are shown in Table 1. All samples were found to be phase-pure within the sensitivity of the XRD data. Unit cell dimensions agreed well with published values for the structure templates. ${ }^{[10]}$

The Ca/P ratios determined by inductively coupled plasmamass spectrometry (ICP-MS) analysis (Table 2) closely matched the theoretical composition of monetite, brushite $(\mathrm{Ca} / \mathrm{P}=1.0)$, and OCP $(\mathrm{Ca} / \mathrm{P}=1.33)$ and thus corroborate the phase purity indicated by the XRD analysis. The slightly lower than expected $\mathrm{Ca} / \mathrm{P}$ ratio of OCP samples is likely due to the presence of sodium $(\mathrm{Na} / \mathrm{P} \approx 0.07)$ substituted into the crystal lattice. Specifically, the ratio $(\mathrm{Ca}+(\mathrm{Na} / 2) / \mathrm{P})$ was 1.35 for OCP.

As is observed in Figure 3, upon aging in cell culture medium over a period of up to $14 \mathrm{~d}$, both BN and BP exhibited newly

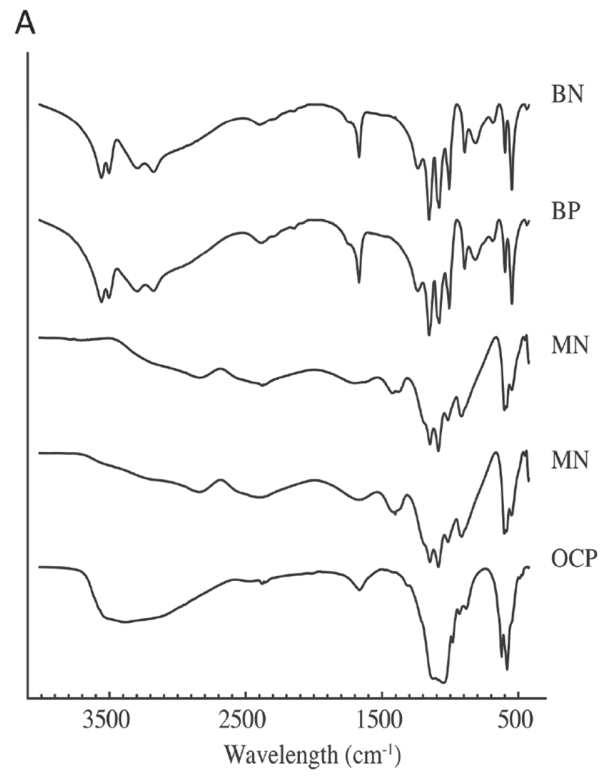

B

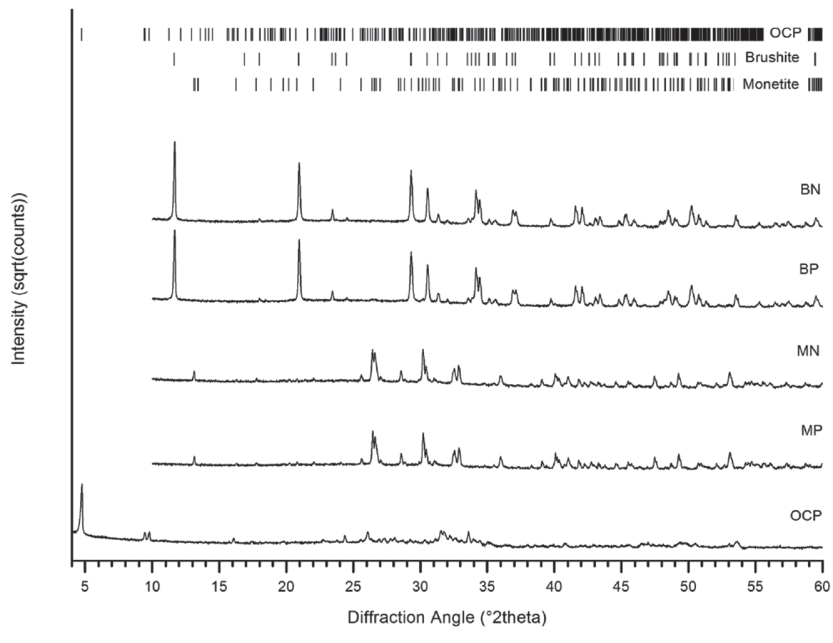

Figure 2. A) FTIR spectra and B) XRD patterns of BN, BP, MN, MP, and OCP. The FTIR spectra of BN and BP were similar, confirming identical chemistry of both shapes of brushite particles. Similarly, resemblance of FTIR spectra of MN and MP indicated that both particle types were of the same chemistry. The distinct FTIR spectrum of OCP was typical of this CaP phase. XRD raw data of OCP were measured from 4 to $60^{\circ} 2 \theta$ to capture the characteristic OCP peak below $5^{\circ} 2 \theta$. All other datasets were measured from 10 to $60^{\circ} 2 \theta$. The vertical axis shows the intensity as the square root of counts to improve legibility. Also the XRD patterns were typical of respectively phase-pure brushite, monetite, and OCP, and confirmed similarity in crystal structure between plate- and needle-shaped particles of the same crystal phase. 
Table 1. Crystallographic parameters of all samples refined from XRD data. Estimated standard deviations as reported by the Rietveld refinement software are given in parentheses. Crystallite sizes refer to the condition after milling in acetone for XRD sample preparation. Refinement of crystallite sizes of the sample "monetite needles" was reduced to isotropic by the Rietveld software's internal refinement strategy algorithms.

\begin{tabular}{|c|c|c|c|}
\hline & $\begin{array}{l}\text { Phase composition and } \\
\text { goodness of fit }\end{array}$ & $\begin{array}{c}\text { Unit cell parameters } \\
{\left[\left[^{\circ},{ }^{\circ}\right]\right.}\end{array}$ & $\begin{array}{c}\text { Crystallite size } \\
{[\mathrm{nm}]}\end{array}$ \\
\hline \multirow[t]{4}{*}{ BN } & 100 wt $\%$ brushite $\chi^{2}=1.23$ & $a: 5.817676(0.000096)$ & $(1,0,0): 399(29)$ \\
\hline & & b: $15.19259(0.00030)$ & $(0,1,0): 581(48)$ \\
\hline & & $c: 6.24658(0.00011)$ & $(0,0,1): 216(8)$ \\
\hline & & $\beta: 116.3884(0.0012)$ & \\
\hline \multirow[t]{4}{*}{ BP } & 100 wt $\%$ brushite $\chi^{2}=1.23$ & a: $5.817065(0.000093)$ & $(1,0,0): 724(111)$ \\
\hline & & b: $15.19280(0.000034)$ & $(0,1,0): 380(20)$ \\
\hline & & c: $6.24565(0.00011)$ & $(0,0,1): 243(10)$ \\
\hline & & $\beta: 116.3886(0.0011)$ & \\
\hline \multirow[t]{6}{*}{ MN } & 100 wt $\%$ monetite $\chi^{2}=1.29$ & $a: 6.90608(0.00020)$ & $(1,0,0): 232(42)$ \\
\hline & & $b: 6.63968(0.00023)$ & $(0,1,0): 232(42)$ \\
\hline & & $c: 6.99399(0.00023)$ & $(0,0,1): 232(42)$ \\
\hline & & $\alpha: 96.3160(0.0023)$ & \\
\hline & & $\beta: 103.9128(0.0020)$ & \\
\hline & & $\gamma .88 .4359(0.0020)$ & \\
\hline \multirow[t]{6}{*}{ MP } & 100 wt $\%$ monetite $\chi^{2}=1.17$ & a: $6.90377(0.00017)$ & $(1,0,0): 195(10)$ \\
\hline & & $b: 6.64039(0.00018)$ & $(0,1,0): 255(17)$ \\
\hline & & c: $6.99310(0.00019)$ & $(0,0,1): 316(21)$ \\
\hline & & $\alpha: 96.3242(0.0017)$ & \\
\hline & & $\beta: 103.9125(0.0017)$ & \\
\hline & & $\gamma .88 .4454(0.0018)$ & \\
\hline \multirow[t]{6}{*}{$\mathrm{OCP}$} & $100 \mathrm{wt} \%$ OCP $\chi^{2}=1.52$ & a: $19.6808(0.0013)$ & $(1,0,0): 231(11)$ \\
\hline & & b: $9.53718(0.00065)$ & $(0,1,0): 132(10)$ \\
\hline & & c: $6.85434(0.00043)$ & $(0,0,1): 48(2)$ \\
\hline & & $\alpha: 90.1770(0.0073)$ & \\
\hline & & $\beta: 92.3248(0.0074)$ & \\
\hline & & $\gamma .108 .1523(0.0058)$ & \\
\hline
\end{tabular}

culture medium, as suggested by the respective FTIR spectra (Figure 4).

The analysis of the $\mathrm{Ca}^{2+}$ and $\mathrm{P}_{\mathrm{i}}$ ionic content of the aging medium, that itself contains $1.95 \times 10^{-3} \mathrm{M} \mathrm{Ca}^{2+}$ and $1.16 \times 10^{-3} \mathrm{M} \mathrm{P}_{\mathrm{i}}$ ions, showed that both $\mathrm{BN}$ and $\mathrm{BP}$ particles released $\mathrm{Ca}^{2+}$ and $\mathrm{P}_{\mathrm{i}}$ (Figure 5). An increased release of both ions was observed with extended aging time of $14 \mathrm{~d}$. The $\mathrm{Ca}^{2+}$ and $\mathrm{P}_{\mathrm{i}}$ ion concentrations obtained for monetite were close to the theoretical values of basic medium and did not change over time. In contrast, upon OCP aging, $\mathrm{Ca}^{2+}$ and $\mathrm{P}_{\mathrm{i}}$ ionic concentrations measured were lower than those found in the medium itself, suggesting uptake of these ions by the OCP particles.

\subsection{Dependence of Cell Behavior on Crystal Phase and Particle Morphology}

Qualitative analysis of cell morphology after 7-d culture on various CaPs in basic medium (Figure 1, last row) showed that on brushite, cells retained a somewhat rounded morphology, independent on the particle shape. They attached onto the relatively smooth surface of plates and adhered preferentially in corners or in between crystals when cultured on needles. On monetite, the cells tended to flatten and spread on the rougher surface. Alike for brushite particles, cells grown on needles were found in the corners formed by entangled crystals. HMSCs cultured on OCP formed a flat sheet covering the sharp crystal flakes.

After 7 and $14 \mathrm{~d}$ of culture in basic or osteogenic medium, DNA was quantified to assess cell proliferation (Figure 6A). The overall amount of DNA retrieved from cul-

deposited mineral, which was composed of flakes that evolved into sharper structures with aging time. Such deposits were not observed on monetite, which, both as plates and as needles, exhibited an increased porosity. In the case of OCP, initially thin and sharp plate-like crystals smoothened in the extremities with aging.

None of the CaPs showed significant chemical modification during the 2-week aging study, by immersion in basic cell

Table 2. $\mathrm{Ca} / \mathrm{P}$ ratios of as-prepared $\mathrm{BN}, \mathrm{BP}, \mathrm{MN}, \mathrm{MP}$, and $\mathrm{OCP}$ determined using ICP-MS analysis.

\begin{tabular}{lc}
\hline & Ca/P ratio \\
\hline BN & $0.995 \pm 0.006$ \\
BP & $0.999 \pm 0.005$ \\
MN & $0.994 \pm 0.002$ \\
MP & $0.998 \pm 0.002$ \\
OCP & $1.317 \pm 0.005$ \\
\hline
\end{tabular}

tures on CaPs was lower than was observed for cultures on tissue culture plates. No significant effect of the medium type on cell proliferation was found. Brushite and monetite both as needles and as plates sustained cell proliferation over the $14 \mathrm{~d}$ of the experiment, in both basic and osteogenic medium, and a significant increase in DNA amount was observed between 7 and $14 \mathrm{~d}$. Proliferation of cells cultured on OCP was limited, with low DNA levels over the 14-d culture period. The amount of DNA measured after $7 \mathrm{~d}$ in cultures on BN was significantly higher than DNA level of cells cultured on the other types of crystals, independent on the type of medium. After $14 \mathrm{~d}$ of culture, no significant differences were found between DNA levels from cultures on brushite and monetite of either morphology. However, cells cultured on brushite and monetite both showed higher DNA levels than those cultured on OCP, independent of the medium used.

Alkaline phosphatase (ALP) enzymatic activity of hMSCs was quantified and corrected for DNA content after 7 and $14 \mathrm{~d}$ of culture (Figure 6B). ALP levels on CaP particles were found 
Brushite needles
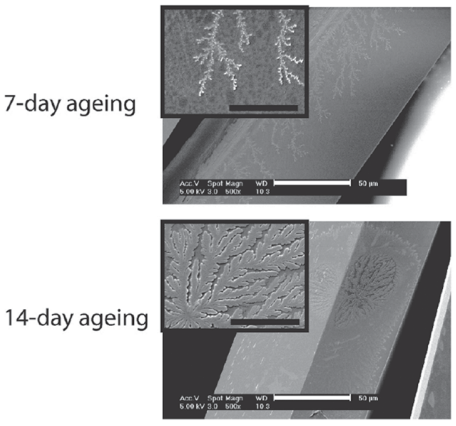

Brushite plates
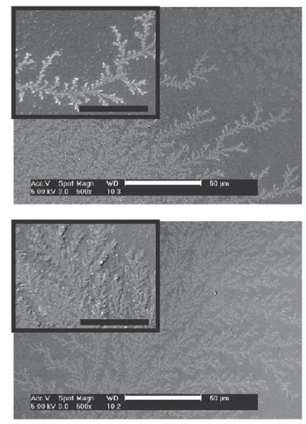

Monetite needles

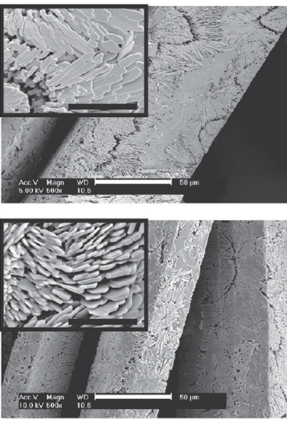

Monetite plates

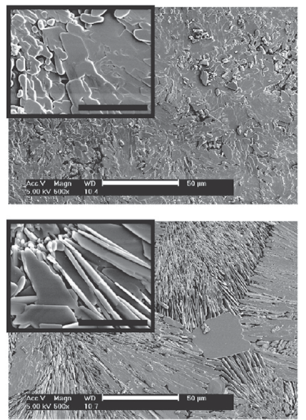

OCP

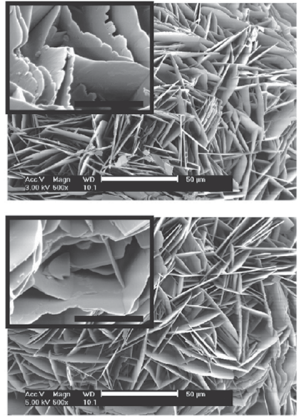

Figure 3. SEM images of $B N, B P, M N, M P$, and $O C P$ after 7- and 14-d aging in basic cell culture medium (scale bar $50 \mu \mathrm{m}$, scale bar insets $10 \mu \mathrm{m}$ ).

to be higher than those measured in control tissue culture plastic cultures, independent of the medium used. A trend of increased ALP expression over time was observed for all conditions except for cells cultured on $\mathrm{MN}$ in basic medium. However, this temporal increase was statistically significant only for cultures on brushite and monetite in osteogenic medium. Additionally, higher ALP production was observed in cells cultured in osteogenic as compared to basic medium, regardless of the $\mathrm{CaP}$ type. In terms of differences among different CaPs, hMSCs cultured on BP presented a significantly higher ALP activity after $7 \mathrm{~d}$ of culture in basic medium and after 7 and $14 \mathrm{~d}$ in osteogenic medium, as compared to other CaPs.

The expression profile of osteogenic markers of hMSCs from donor 1 , as determined using quantitative real-time polymerase chain reaction (QPCR) is displayed in Figure 7. ALP mRNA transcript expression was downregulated in cells cultured on

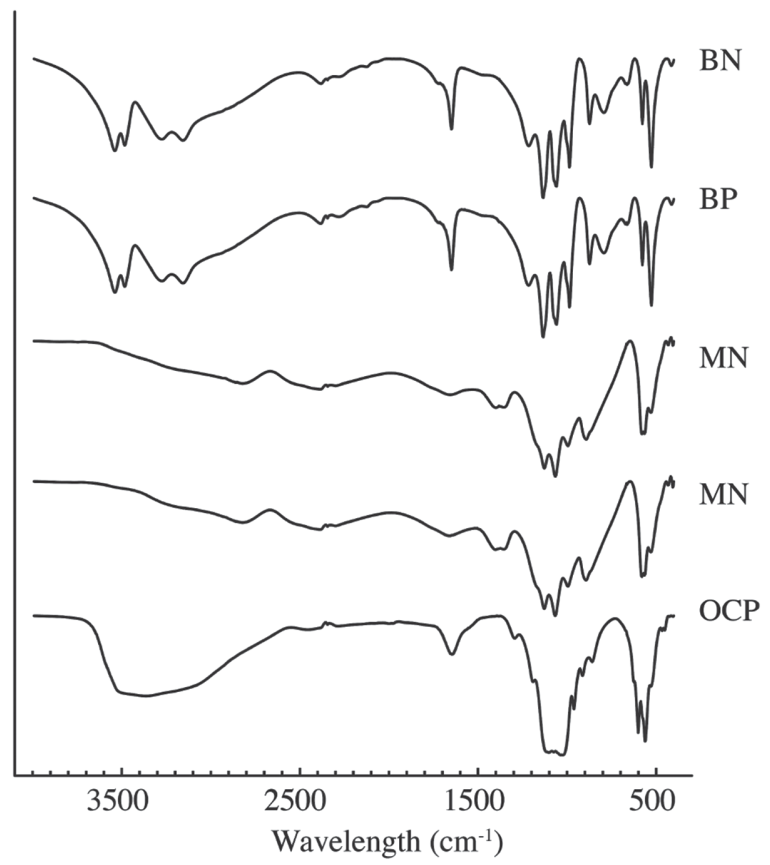

Figure 4. FTIR spectra of BN, BP, MN, MP, and OCP particles after 14-d aging in basic cell culture medium.
CaPs at both time points and in both media as compared to cells cultured on tissue culture plastic in basic medium. This was in contrast to the ALP activity, possibly because the peak of the ALP mRNA expression, which is transient, occurs later on 2D tissue culture plastic than on CaPs, and was thus not yet visible in the ALP activity. Regarding differences among different CaPs, cells cultured in osteogenic medium on BP expressed significantly higher levels of ALP than cells cultured on the other $\mathrm{CaP}$, at both 7 and $14 \mathrm{~d}$, which is in accordance with the ALP enzymatic activity.

BMP2 mRNA expression was significantly higher in basic medium than in osteogenic medium for all CaPs and both time points, but not for cells cultured on tissue culture plastic. For cells cultured on CaP particles, BMP2 levels approximately doubled between 7 and $14 \mathrm{~d}$ of culture. HMSCs cultured on OCP in basic medium showed a significantly higher BMP2 expression than cells cultured on all other CaPs and tissue culture plastic, at both 7 and $14 \mathrm{~d}$. BN have shown the lowest expression of BMP2 among the different CaPs, which was highlighted by statistically significant differences with MP after 7 and $14 \mathrm{~d}$, and with MN after $14 \mathrm{~d}$.

Analogous to BMP2, cells cultured on CaPs in basic medium showed a significantly higher expression of OP as compared to cells cultured in osteogenic medium, while this trend was not observed in cells cultured on tissue culture plastic. Cells cultured on the CaP particles showed a significant temporal increase of the OP expression. HMSCs cultured on BP, MN, $\mathrm{MP}$, and OCP in basic medium expressed significantly higher levels of OP mRNA as compared to cells cultured on tissue culture plastic at 7 and $14 \mathrm{~d}$. Cells cultured in basic medium on BN expressed significantly lower levels of OP than cells cultured on the other CaPs, at both 7 and $14 \mathrm{~d}$, with the exception of $\mathrm{BP}$ at $7 \mathrm{~d}$.

OC expression was higher for cells grown in basic medium as compared to cells cultured in osteogenic medium, independent of the time point, although this difference was not statistically significant for cells cultured on $\mathrm{MN}$ at $7 \mathrm{~d}$, and on $\mathrm{BN}$ and $\mathrm{MN}$ at $14 \mathrm{~d}$. No temporal changes in the expression of OC mRNA were observed. Although differences among mRNA levels were not large, the statistical analysis revealed that cells cultured in basic medium on BN, MN, and MP expressed a significantly lower level of OC as compared to cells grown on BP, OCP, and controls at both time points. 

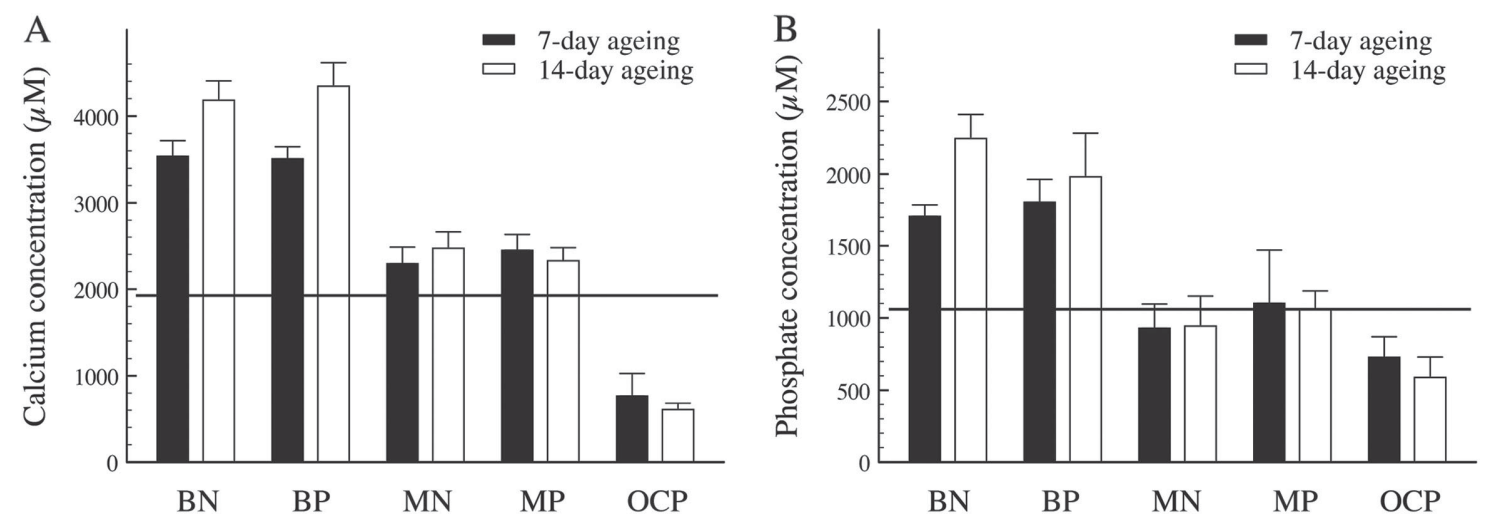

Figure 5. A) Calcium and B) inorganic phosphate ion concentration in the aging medium. The lines represent the theoretical concentrations of $\mathrm{Ca}^{2+}$ and $\mathrm{P}_{\mathrm{i}}$ ions in basic cell culture medium.

To investigate the effect of donor variation on the osteogenic differentiation of hMSCs cultured on CaPs, the expression of ALP, BMP2, and OP was investigated for cells from a second donor, in a 7-d basic medium cell culture (Figure 8). Comparable to the cells of the first donor, ALP mRNA expression was lower in cells cultured on CaPs as compared to those cultured on tissue culture plastic in either medium. OCP was shown to induce a significantly higher expression of BMP2 than all other $\mathrm{CaP}$ particles or tissue culture plastic. Furthermore, hMSCs cultured on OCP also expressed a significantly higher level of OP as compared to culture on tissue culture plastic, independent of the medium used.

\section{Discussion}

The aim of this study was to obtain a better understanding of the effects of the crystal phase and particle morphology of naturally occurring, biomimetic CaPs on the behavior of clinically relevant hMSCs. By closely controlling the precipitation conditions, we obtained CaPs with distinct phase and morphology. Precipitation of brushite crystals at mildly acidic conditions has also been shown in previous studies, demonstrating the possibilities to control the morphology of the precipitates by tuning the precipitation conditions. ${ }^{[18-21]}$ We employed this method to produce brushite particles, which were either needle- or plate-shaped, and by autoclaving these particles, we obtained monetite with the same morphologies. Brushite and monetite were both phase-pure, as was confirmed by the XRD and ICP-MS analyses. The crystallite sizes differed between the two phases as well as between the morphologies of the same phase, however, it should be noted that crushing and milling of the samples prior to XRD data collection reduced the mean crystallite size and therefore, the values are not representative of as-precipitated crystals. Surface microstructure of the two phases showed distinct differences. Brushite particles, which were single crystals, as demonstrated using polarized microscopy, showed a smooth surface morphology. In contrast, monetite particles were polycrystalline, consisting of multiple layered, flake-like crystals. Quantification of specific surface

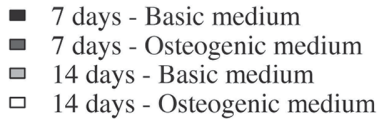

- 7 days - Basic medium

ㅁ 14 days - Basic medium

$\square 14$ days - Osteogenic medium
A

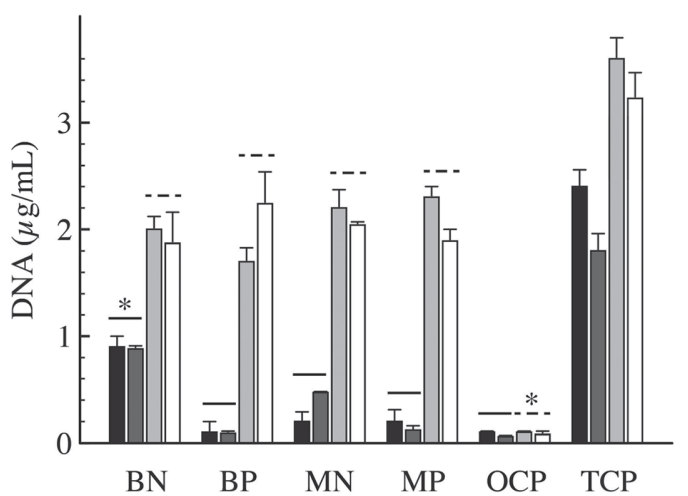

B

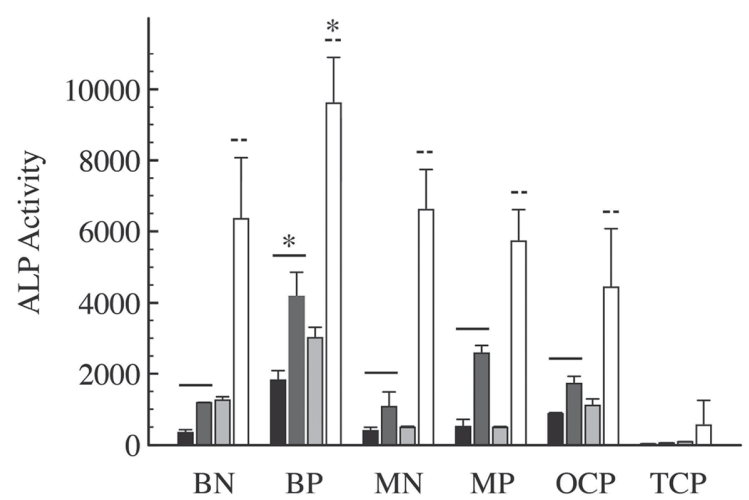

Figure 6. A) DNA content and B) ALP activity corrected for DNA content of hMSCs cultured on BN, BP, MN, MP, OCP, and tissue culture plates in basic and osteogenic medium for 7 and $14 \mathrm{~d}$. 
Alkaline Phosphatase
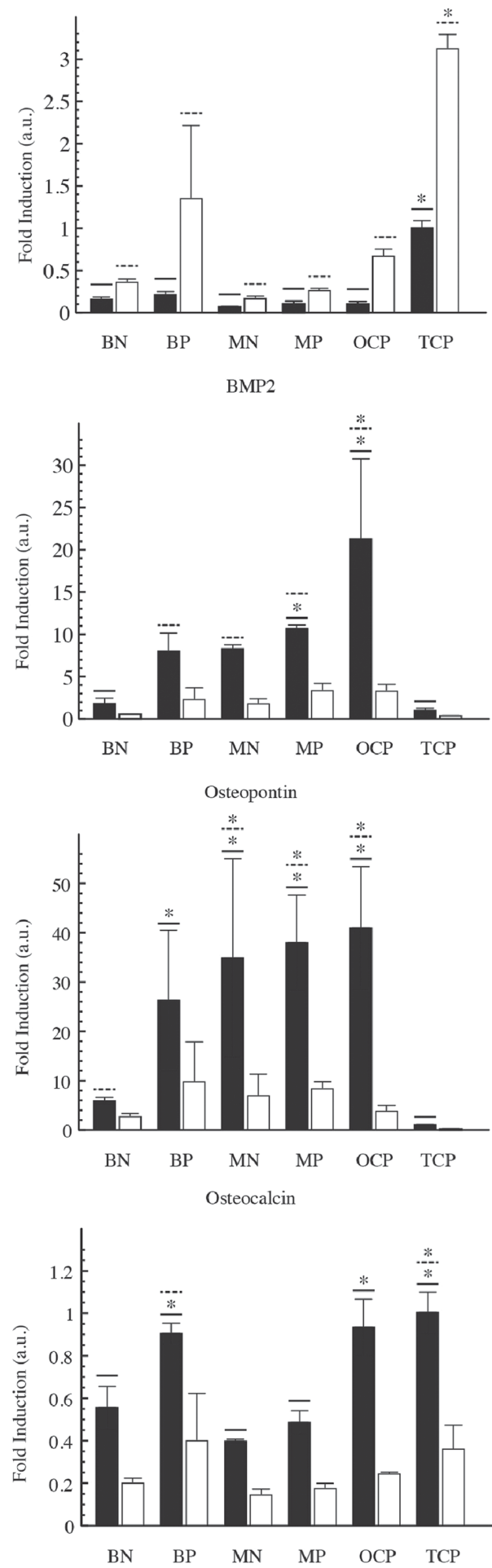

Alkaline Phosphatase
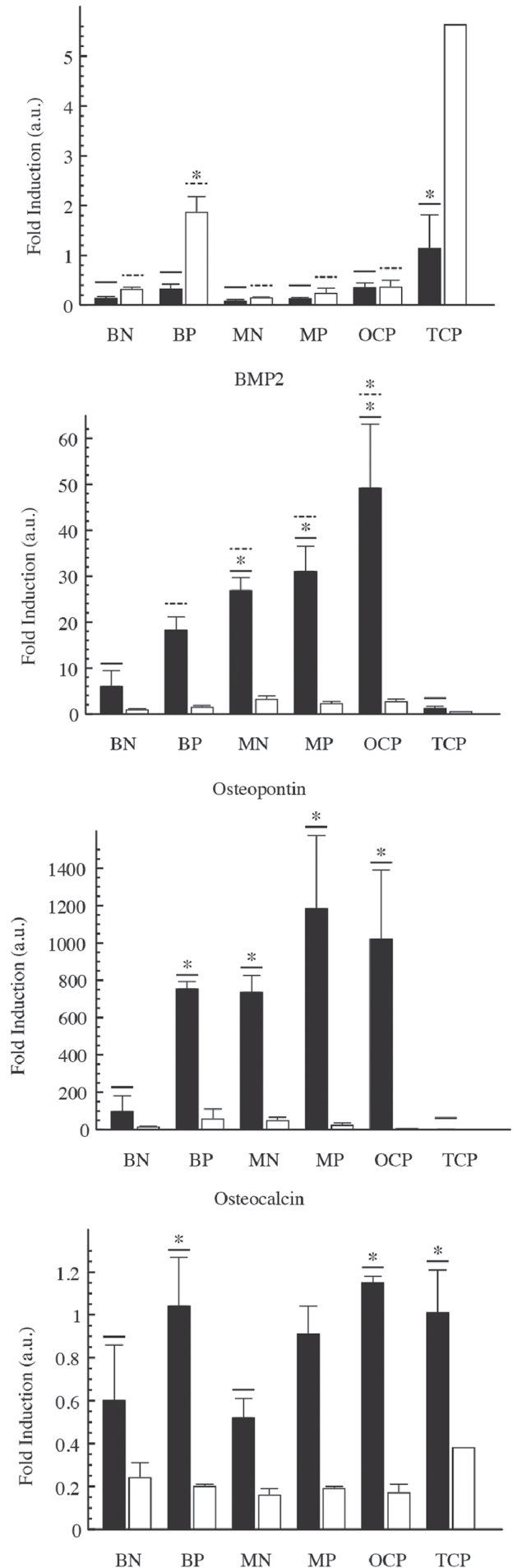

Figure 7. The expression of a panel of osteogenic markers at mRNA level by hMSCs of Donor 1 after 7 (left panel) and 14 (right panel) d of culture on $\mathrm{BN}, \mathrm{BP}, \mathrm{MN}, \mathrm{MP}$, and OCP in basic medium (black bars) and osteogenic medium (white bars). Cells cultured on tissue culture plastic served as controls.

area confirmed that monetite had a surface area that was about two orders of magnitude higher than that of brushite. Finally, OCP precipitates were included for their distinct crystal phase and morphology, consisting of spherical particles that were built of perpendicularly oriented plate-shaped crystals, and a specific surface area that was approximately twice that of monetite. In order to study changes in crystal phase and morphology upon hydrolysis, the CaPs were immersed in cell culture medium, 

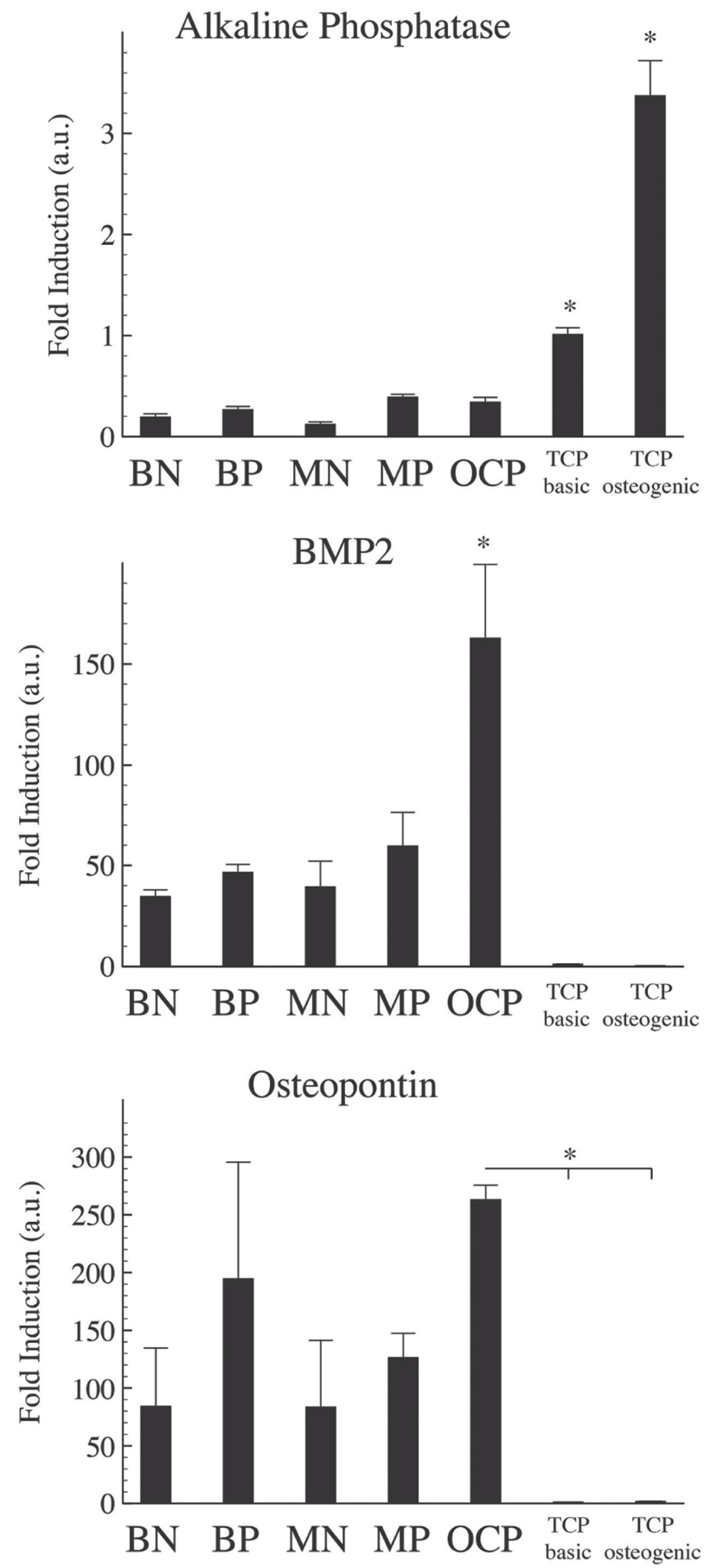

Figure 8. The expression of a panel of osteogenic markers at mRNA level by hMSCs of Donor 2 after $7 \mathrm{~d}$ of culture on BN, BP, MN, MP, and OCP in basic cell culture medium. Cells cultured on tissue culture plastic in either basic or osteogenic medium served as controls.

similar to that used for cell culture experiments, to mimic changes that occur during cell culture. On smooth brushite crystals, the only apparent morphological changes were deposits of a new mineral, although no significant changes were observed on FTIR spectra of the material after aging, which may be due to a relatively small amount deposited. In the case of monetite, sharpening of crystal edges and increased spaces between individual crystals were seen, suggesting dissolution. In contrast, OCP particles smoothened on the edges, which is in accordance with previous study by Barrere et al., ${ }^{[22]}$ where conversion of OCP into carbonated apatite was observed. Such a change in phase was not observed in the present study based on the FTIR data, which is possibly because of differences in crystal size between the two studies. Analysis of the ionic concentration of the immersion medium during aging indicated that both brushite and monetite released $\mathrm{Ca}^{2+}$ and $\mathrm{P}_{\mathrm{i}}$ ions into the medium, though to different extents, with brushite releasing about 1.5 times more ions than monetite. In OCP immersed solutions, however, a decrease of $\mathrm{Ca}^{2+}$ and $\mathrm{P}_{\mathrm{i}}$ ions was observed, suggesting precipitation. Based on the theoretical solubility product constants at neutral $\mathrm{pH}$, brushite is the most soluble of the three, followed by monetite and OCP, ${ }^{[23]}$ which is in accordance with the data observed here. Nevertheless, in solutions that are saturated with $\mathrm{Ca}^{2+}$ and $\mathrm{P}_{\mathrm{i}}$, it has been shown that not the release, but an uptake of the ions occurs upon immersion, a phenomenon that is dependent on the specific surface area. ${ }^{[24]}$ It should be noted that the medium was not refreshed during the aging experiment, in contrast to cell culture experiments that require frequent medium refreshment. Nevertheless, considering that the cell culture medium is saturated with $\mathrm{Ca}^{2+}$ and $\mathrm{P}_{\mathrm{i}}$, we do not expect a strong effect of the medium refreshment.

Regarding the attachment of cells on various CaPs, it was observed that both the morphology of the particle and its surface microstructure affected the attachment and spreading of hMSCs. In both BN and MN, the cells preferentially attached to the material in the corners between entangled crystals, while on the plate-shaped particles of both phases, they were found on the planar surface. Spreading was more pronounced on the rougher, and less soluble monetite than on the brushite where the cell area remained relatively small. Surface roughness has previously been shown to affect cell shape, cytoskeleton and adhesion. ${ }^{[25]}$ Cell attachment and spreading was poor on OCP, which is possibly related to the sharp morphology of OCP crystals comprising the globular particles. This finding was in accordance with previous studies in which either rat periosteal and bone marrow stromal cells ${ }^{[26]}$ or mouse bone marrow stromal ST-2 cells ${ }^{[27]}$ were used.

This initial cell attachment was also reflected in the total DNA amount determined after 7 and $14 \mathrm{~d}$ of culture, which provides an indication of cell proliferation. While for brushite and monetite, a significant increase in DNA amount was observed between days 7 and 14, no increase was seen when cells were cultured on OCP. Poor proliferation of cells on OCP was in accordance with previous work. ${ }^{[27]}$ During the initial $7 \mathrm{~d}$, BN seemed to better support hMSCs proliferation than other CaPs, however, after $14 \mathrm{~d}$, the only significant difference was that between OCP and other CaPs. Both $\mathrm{Ca}^{2+}$ and $\mathrm{P}_{\mathrm{i}}$ ions were previously shown to affect proliferation of hMSCs, ${ }^{[8,28]}$ however also surface energy, surface roughness, and other surface topographical features may have an influence on proliferation, emphasizing the difficulty of attributing a biological response to a single property in the case of complex biomaterials. Osteogenic differentiation of the cells was first assessed by the ALP enzyme activity. ALP is considered an early marker of osteogenesis $^{[29]}$ that is known for its ability to convert extracellular 
pyrophosphate, a mineralization inhibitor, into $\mathrm{Pi}^{[30]} \mathrm{An}$ increase in ALP activity was shown on all CaPs between days 7 and 14, suggesting support of osteogenic differentiation. The levels of ALP were higher in the BP condition as compared to the other CaPs when cells were cultured in the osteogenic medium. These results were confirmed when the expression of ALP at the mRNA level was analyzed. In general, in all conditions, the expression was higher in osteogenic than in basic medium, though it remained relatively low for BN, MN, MP, and OCP. The expression of both BMP2 and OP of cells cultured on the CaPs was always higher in basic than in osteogenic medium, an observation that is in accordance with other studies combining hMSCs and CaP ceramics. ${ }^{[7,8,31]}$ Unlike ALP, that is known to be upregulated in hMSCs by the addition of dexamethasone to the medium, its effect on the expression of BMP2 and OP is not as obvious. ${ }^{[32]} \mathrm{BMP} 2$ has a well-established role in the process of osteogenic differentiation, ${ }^{[33]}$ while OP is thought to inhibit hydroxyapatite formation and growth during bone mineralization. ${ }^{34]}$ For both markers, the general trend was an increasing expression from $\mathrm{BN}$, to BP, followed by $\mathrm{MN}$, $\mathrm{MP}$, and a highest expression on OCP. A significant difference between BN and BP was only found for the OP expression, in the case of one donor, while the difference between $\mathrm{BN}$ and all other CaPs was significant for cells of both donors. BMP2 expression of cells cultured on OCP was significantly higher than on all other CaPs, for both donors tested, while both MN and MP showed a significantly higher expression than cells cultured on $\mathrm{BN}$. It has been previously shown that both OP and BMP2 are calcium-responsive genes, and their expression observed here seems to be positively correlated with the specific surface area, and negatively with the amount of free $\mathrm{Ca}^{2+}$ and $\mathrm{P}_{\mathrm{i}}$ ions in the solution. As was mentioned before, a lower amount of these ions in the medium, in the case of OCP even lower than the initial medium concentration, may actually mean precipitation of a new CaP phase, and thus temporarily a supersaturation of these ions in the material vicinity. Since cells are found in contact with the material, it is proposed that the upregulation of BMP2 and, to a lesser extent of OP on OC is due to this increased local $\mathrm{Ca}^{2+}$ concentration. Differences among the materials were also found for the expression of OC, known for its regulatory role in the growth of hydroxyapatite crystals during bone formation, ${ }^{[34]}$ however, they were small. To the best of our knowledge, no direct comparison exists of the three CaP phases described here in terms of the effect on hMSCs behavior. However, a previous direct in vitro comparison of brushite and monetite using mouse bone marrow derived stromal cells suggested a more pronounced osteogenic differentiation on monetite as compared to brushite based on the mRNA expression of a number of osteogenic markers including ALP, OP, and OC, although the differences were relatively small. ${ }^{11]}$ A positive effect of OCP on the osteogenic differentiation of mouse MSCs in terms of the expression of ALP, osterix, and collagen type I has also been described before. ${ }^{[27]}$

Taken together, the results of this study suggest that when comparing different CaPs, both the crystal phase and the crystal/particle morphology affect the proliferation and osteogenic differentiation of hMSCs. We observed differences in attachment and spreading on different $\mathrm{CaPs}$, as a consequence of particle morphology and surface microstructure, inhibition of hMSCs proliferation on OCP as compared to brushite and monetite, and in general a higher expression of the markers of osteogenic differentiation on plate-shaped particles and OCP as compared to needle-shaped particles. These data are useful for designing and developing new CaP-based bone graft substitutes. Nevertheless, this study also shows the limitations of the conventional methods to control individual properties of CaPs. Although we were able to produce two phase-pure $\mathrm{CaP}$ phases both as needles and as plates, it should be emphasized that there were more differences between them than only the particle morphology. While brushite was shown to consist of single crystals, monetite was polycrystalline. As a result, their surface microstructure differed, and therewith also their specific surface area, which further affected their dissolution in an aqueous environment. Also the roughness and the surface energy of the crystals were plausibly different between different crystal phases and even between different faces of a crystal. Regarding the two particle morphologies of the same crystal phase, we have shown that they were both phase-pure, with identical lattice parameters however, properties of different crystal faces could still be different. Therefore, in order to obtain conclusive evidence for the effect of individual properties, it is suggested to employ combinations of techniques and materials, like recently reported for decoupling chemistry from structural properties ${ }^{[7]}$ and stiffness from other physico-chemical properties of $\mathrm{CaPs},{ }^{[2]}$ instead of relying on the possibilities that a synthesis- or a production technique offers.

\section{Conclusions}

Understanding the relationship between the individual properties of a functional biomaterial and a biological response is a prerequisite for the rational design of new, improved synthetic substitutes for patient's own tissue, the need for which is rapidly growing. In this study, it has been demonstrated that both the crystal phase and the structural properties of $\mathrm{CaP}$ ceramics, being widely used bone graft substitutes, have distinct effects on the growth and differentiation of clinically relevant bone marrow-derived hMSCs. Although successful, the method used here is limited in terms of parameters that can be reliably tested, and other methods need to be employed to obtain a full understating of property-biological response relationship of complex biomaterials such as $\mathrm{CaP}$ ceramics.

\section{Experimental Section}

CaP Synthesis: Brushite and OCP were synthesized by means of homogeneous crystallization in sterile solutions prepared in MilliQ water. To this end, each solution was filtered through a sterile disposable filter unit with SFCA membrane of $0.2 \mu \mathrm{m}$ pore size (Nalgene) prior to mixing.

The precipitation of brushite was based on a previously published method. ${ }^{[19]}$ BN particles were produced by mixing equal volumes of $0.25 \mathrm{~m}$ calcium chloride (Merck) and $0.25 \mathrm{M}$ dibasic ammonium phosphate (Sigma) solutions. Prior to mixing, the $\mathrm{pH}$ of the phosphate solution was adjusted to 4 with $0.25 \mathrm{~m}$ phosphoric acid (Sigma). After mixing, the resulting solution was diluted to a final phosphate concentration of $0.2 \mathrm{~m}$ and kept at $40^{\circ} \mathrm{C}$ for $48 \mathrm{~h}$. 
BP particles were synthesized by mixing equal volumes of $0.25 \mathrm{M}$ calcium nitrate (Sigma) and $0.25 \mathrm{~m}$ monobasic ammonium phosphate (Sigma) solutions. Upon mixing, the solution was kept at $40^{\circ} \mathrm{C}$ for $48 \mathrm{~h}$.

OCP particles were produced using a modified method previously described by Newesely. ${ }^{[35]}$ In short, $450 \mathrm{~mL} 40 \times 10^{-3} \mathrm{M}$ calcium chloride (Sigma) solution, $450 \mathrm{~mL} 30 \times 10^{-3} \mathrm{M}$ disodium hydrogen orthophosphate (Merck) solution and $4.5 \mathrm{~L} 0.2 \mathrm{~m}$ sodium acetate (Sigma) solution were prepared and mixed. The $\mathrm{pH}$ of the sodium acetate solution was adjusted with phosphoric acid ( $85 \mathrm{wt} \%$ in $\mathrm{H}_{2} \mathrm{O}$-Sigma) to $\mathrm{pH} 6.5$ prior to mixing. The final solution was kept at $45^{\circ} \mathrm{C}$ for $48 \mathrm{~h}$.

Upon precipitation, brushite and OCP were collected from the respective solutions, rinsed with $70 \%$ ethanol and dried at $37{ }^{\circ} \mathrm{C}$ overnight.

Monetite particles were obtained by autoclaving brushite particles at $120^{\circ} \mathrm{C}$ for $20 \mathrm{~min}$.

Material Characterization: Particle morphology and surface structure were examined using SEM (XL30, ESEM-FEG, Philips, The Netherlands, in the secondary electron mode with an acceleration voltage of 5 to $10 \mathrm{kV}$ ). The internal grain architecture was analyzed by polarized light microscopy on a Leica M205A (Leica Mikrosysteme, Wetzlar, Germany) optical microscope reaching a maximum magnification factor of 100. As-synthesized precipitates were spread on a glass plate without cover and observed in cross-polarized light. Single and polycrystals were identified based on their birefringence pattern and direction of extinction. Chemical characterization of the CaPs was performed using transmission-mode FTIR (Spectrum100, Perkin Elmer Analytical Instruments, Norwalk, CT, USA) with a spectral resolution of $2 \mathrm{~cm}^{-1}$, using potassium bromide $(\mathrm{KBr})$ pellets. The crystalline phase composition and crystallographic parameters of the synthesized materials were determined by powder XRD on a Bruker D8 diffractometer (Bruker, Karlsruhe, Germany), equipped with a $\mathrm{Cu} \mathrm{K} \alpha \mathrm{X}$-ray tube and a linear energy dispersive detector. The sample material was crushed and milled in acetone using an agate mortar and pestle, and then transferred into glass capillaries $(480 \mu \mathrm{m}$ inner diameter, Hilgenberg special glass No. 10, Hilgenberg, Germany), and measured from 4 to $60^{\circ} 2 \theta$ in case of OCP, and from 10 to $60^{\circ} 2 \theta$ in case of monetite and brushite, with a step size of $0.0122^{\circ} 2 \theta$ and a counting time of 6 s per step. The data sets were evaluated by Rietveld refinement using the software Profex (version $3.8^{[36]}$ ) with the Rietveld kernel BGMN (version 4.2.22 ${ }^{[37]}$ ). Crystal structure templates were taken from Curry and Jones ${ }^{[38]}$ for brushite, from Dickens et al..$^{[39]}$ for monetite, and from Mathew et al. ${ }^{[40]}$ for OCP. Crystallite sizes were determined from anisotropic peak broadening using the Rietveld kernel's internal algorithms.

In order to quantify the elemental composition, $\mathrm{CaP}$ samples were dissolved in $69 \% \mathrm{HNO}_{3}(\mathrm{w} / \mathrm{w})\left(\mathrm{HNO}_{3}\right.$, TraceSELECT, Sigma Aldrich, Switzerland) and diluted 1:1000 in a solution of demineralized $\mathrm{H}_{2} \mathrm{O}$ containing $3 \% \mathrm{HNO}_{3}, 2 \% \mathrm{HCl}(\mathrm{HCl}$, Rotipuran Supra, Carl Roth, Switzerland), and $0.01 \% \mathrm{HF}$ (HF, TraceSELECT Ultra, Sigma Aldrich, Switzerland). The solutions were analyzed using ICP-MS (Agilent 7700x, Agilent Technologies, Japan). ${ }^{44} \mathrm{Ca}$ and ${ }^{31} \mathrm{P}$ signals were calibrated against a custom-made certified standard solution containing $\mathrm{Ca}$ and $\mathrm{P}_{\mathrm{i}}$ ions in a molar ratio of 0.98 , and ${ }^{23} \mathrm{Na},{ }^{25} \mathrm{Mg}$, and ${ }^{88} \mathrm{Sr}$ signals were calibrated against a multi-element standard solution (both: Inorganic Ventures, USA). Calibration drifts were corrected according to the Ca-P standard measured after every eighth sample and according to a $20 \mathrm{ppb}$ internal $\mathrm{In} / \mathrm{Sc} / \mathrm{Bi}$ standard solution (Inorganic Ventures, USA) measured along with each sample. Finally, the mean values of four measurements per sample were determined.

A quantification of the surface area of precipitates was obtained with the Brunauer-Emmett-Teller (BET) method using a nitrogen adsorption volumetric technique (TriStar 3000, Micromeritics, USA).

$\mathrm{CaP}$ Aging in Cell Culture Medium: Chemical and morphological changes of the $\mathrm{CaP}$ particles in aqueous environment were monitored upon immersion in the basic cell culture medium $(\alpha$-minimal essential medium (Gibco), 10\% fetal bovine serum (Lonza), $0.2 \times 10^{-3} \mathrm{M}$ ascorbic acid (Sigma Aldrich), $2 \times 10^{-3} \mathrm{M}$ L-glutamine (Gibco), 100 units $\mathrm{mL}^{-1}$ penicillin (Gibco), $10 \mu \mathrm{g} \mathrm{mL} \mathrm{mL}^{-1}$ streptomycin (Gibco)) for 7 and $14 \mathrm{~d}$. Briefly, $40 \mathrm{mg}$ of particles of each type were placed in separate wells of a 24-well plate (Costar Corning, New York, USA) with $1.5 \mathrm{~mL}$ basic cell culture medium and kept in an incubator at $37^{\circ} \mathrm{C}$ in a humid atmosphere with $5 \% \mathrm{CO}_{2}$ for 7 or $14 \mathrm{~d}$ without refreshment. Chemical characterization of the materials was performed after $14 \mathrm{~d}$ by using FTIR spectroscopy. $\mathrm{Ca}^{2+}$ and $\mathrm{P}_{\mathrm{i}}$ ionic concentrations of the aging medium were analyzed after 7 and $14 \mathrm{~d}$ for independent triplicates by using a quantitative colorimetric method (QuantiChrom Calcium assay kit (DICA-500) and QuantiChrom Phosphate assay kit (DIPI-500), respectively). Optical density of solutions after adding reagents from the kits was determined with a microplate spectrophotometer (Multiskan GO, Thermo Scientific, USA) at 612 and $620 \mathrm{~nm}$ for $\mathrm{Ca}^{2+}$ and $\mathrm{P}_{\mathrm{i}}$ release, respectively. SEM was used to analyze morphological changes of the particles upon 7- and 14-d aging.

Cell Culture Study: Bone marrow aspirates from healthy patients were obtained after written informed consent, and hMSCs were isolated and expanded as described previously. ${ }^{[41,42]}$ Briefly, aspirates were resuspended by using 20-gauge needles, plated at a density of $5 \times 10^{5}$ cells $\mathrm{cm}^{-2}$ and cultured in hMSC proliferation medium containing $\alpha$-minimal essential medium (Gibco), 10\% fetal bovine serum (Lonza), $0.2 \times 10^{-3} \mathrm{M}$ ascorbic acid (Sigma Aldrich), $2 \times 10^{-3} \mathrm{M}$ L-glutamine (Gibco), 100 units $\mathrm{mL}^{-1}$ penicillin (Gibco), $100 \mu \mathrm{g} \mathrm{mL}$ streptomycin (Gibco), and $1 \mathrm{ng} \mathrm{mL}^{-1}$ basic fibroblast growth factor (FGF) (Fisher Scientific). Cells were grown at $37{ }^{\circ} \mathrm{C}$ in a humidified atmosphere with $5 \% \mathrm{CO}_{2}$ with biweekly medium refreshment. Upon reaching subconfluency, the cells were detached using $0.25 \%$ trypsin in ethylene-diamine-tetraacetic acid (EDTA) (Gibco, Life Technologies) for $5 \mathrm{~min}$ at $37^{\circ} \mathrm{C}$ and either seeded on the CaPs, or cryopreserved.

Prior to cell culture, OCP and monetite were autoclaved at $120^{\circ} \mathrm{C}$ for $20 \mathrm{~min}$. This procedure did not have an effect on the OCP stability (data not shown). After weighing, CaP particles were placed in ultra-low attachment 24-well plates (Costar Corning, New York, USA) to minimize the adhesion of cells to the plate. The samples were then rinsed twice with $70 \%$ ethanol at room temperature, followed by washing with sterile PBS upon complete evaporation.

$\mathrm{CaP}$ samples were pre-conditioned in proliferation medium overnight in a humidified atmosphere with $5 \% \mathrm{CO}_{2}$ prior to cell seeding.

To assess proliferation and ALP enzymatic activity on different $\mathrm{CaPs}$, hMSCs from one donor were used. Twenty thousand cells of passage 3 were seeded onto $40 \mathrm{mg}$ of CaP particles in $1.5 \mathrm{~mL}$ of proliferation medium and cultured for 7 or $14 \mathrm{~d}$. HMSCs proliferation was evaluated by quantifying DNA content (CyQUANT Cell Proliferation assay, Life Technologies) and ALP activity was assessed at the enzymatic level (CDP-Star Reagent, Roche) as a marker for osteogenic differentiation.

To investigate the influence of the CaP particles on the osteogenic gene expression, third passage hMSCs from two donors, including the one used for cell proliferation and ALP enzymatic activity assessment, were used. Two hundred thousand cells were seeded onto $120 \mathrm{mg}$ of particles in $1.5 \mathrm{~mL}$ of proliferation medium. Culture-treated 6-well plates (Costar Corning, New York, USA) in which cells were seeded at a density of 50000 cells per well in $3 \mathrm{~mL}$ of proliferation medium served as control material. After $24 \mathrm{~h}$, proliferation medium was replaced by either basic (proliferation medium without bFGF) or osteogenic medium (basic medium supplemented with $10 \times 10^{-9} \mathrm{M}$ dexamethasone). Cells were cultured for 7 or $14 \mathrm{~d}$ at $37^{\circ} \mathrm{C}$ in a humidified atmosphere with $5 \%$ $\mathrm{CO}_{2}$, with refreshment of medium every $2-3 \mathrm{~d}$.

Total RNA was isolated from cultures using a combination of the TRIzol (Invitrogen) method with the NucleoSpin RNA II isolation kit (Macherey-Nagel). $1 \mathrm{~mL}$ of TRIzol reagent was added to each well. Following one freeze/thaw cycle, $200 \mu \mathrm{L}$ chloroform was added per sample. After mixing and centrifugation, the aqueous phase of each sample was collected and mixed with $350 \mu \mathrm{L} 70 \%$ ethanol before loading onto the RNA binding column of the NucleoSpin RNA II isolation kit. Subsequent steps were in accordance with the manufacturer's protocol. First strand cDNA was synthesized using iScript (Bio-Rad). QPCR was performed and $C T$ values were normalized to the Glyceraldehyde 3-phosphate dehydrogenase (GAPDH) housekeeping gene and fold induction was calculated using the comparative $\triangle C T$ method. Primer sequences of the selected markers are given in Table 3. All analyses were performed in triplicate. 
Table 3. Primers sequences for human genes.

\begin{tabular}{|c|c|}
\hline Name & Primer sequence \\
\hline \multirow[t]{2}{*}{ Alkaline phosphatase (ALP) } & $5^{\prime}$-GACCCTTGACCCCCACAAT-3' \\
\hline & 5'-GCTCGTACTGCATGTCCCCT-3' \\
\hline Bone Morphogenetic Protein 2 (BMP2) & Purchased (SA Biosciences) \\
\hline \multirow{2}{*}{$\begin{array}{l}\text { Glyceraldehyde 3-phosphate } \\
\text { dehydrogenase (GAPDH) }\end{array}$} & 5'-СGCTCTCTGCTCCTCCTGTT-3' \\
\hline & 5'-CCATCGTGTCTCACCGATCT-3' \\
\hline \multirow[t]{2}{*}{ Osteocalcin (OC) } & $5^{\prime}$-GGCAGCGAGGTAGTGAAGAG-3' \\
\hline & 5-GATCTCGTCACCCAACTCGT-3' \\
\hline \multirow[t]{2}{*}{ Osteopontin (OP) } & $5^{\prime}$-CCAAGTAAGTCCAACGAAAG-3' \\
\hline & 5'-GGTGATGTCCTCGTCTGTA-3' \\
\hline
\end{tabular}

Statistical Analysis: One-way ANOVA with Tukey's multiple comparison post-hoc test was performed to analyze DNA, ALP, and QPCR data. The level of significance was set at 0.05 . All data presented are expressed as mean \pm standard deviation.

\section{Supporting Information}

Supporting Information is available from the Wiley Online Library or from the author.

\section{Acknowledgements}

CD acknowledges the financial support by the TeRM Smart Mix Program of the Netherlands Ministry of Education, Culture, and Science. This project has been in part made possible with the support of the Dutch Province of Limburg.

Received: February 18, 2016 Revised: April 18, 2016 Published online: May 27, 2016

[1] D. Williams, Essential Biomaterials Science, Cambridge University Press, Cambridge 2014.

[2] G. Mattei, C. Ferretti, A. Tirella, A. Ahluwalia, M. Mattioli-Belmonte, Sci. Rep. 2015, 5, 10778.

[3] S. Y. Chou, P. R. Krauss, P. J. Renstrom, J. Vac. Sci. Technol. B 1996, $14,4129$.

[4] S. Dorozhkin, BIO 2011, 1, 1.

[5] W. Habraken, P. Habibovic, M. Epple, M. Bohner, Mater. Today 2016, 19,69.

[6] P. Habibovic, J. E. Barralet, Acta Biomater. 2011, 7, 3013.

[7] C. Danoux, L. Sun, G. Kocer, Z. T. Birgani, D. Barata, J. Barralet, C. van Blitterswijk, R. Truckenmuller, P. Habibovic, Adv. Mater. 2016, 28, 1803.

[8] C. B. Danoux, D. C. Bassett, Z. Othman, A. I. Rodrigues, R. L. Reis, J. E. Barralet, C. A. van Blitterswijk, P. Habibovic, Acta Biomater. 2015, 17,1 .

[9] M. S. Johnsson, G. H. Nancollas, Crit. Rev. Oral Biol. Med. 1992, 3, 61.

[10] J. C. Elliot, Surface Chemistry of the Apatites and Other Calcium Orthophosphates, Elsevier Sciences, Amsterdam 1994.
[11] F. Tamimi, Z. Sheikh, J. Barralet, Acta Biomater. 2012, 8, 474.

[12] W. E. Brown, J. P. Smith, J. R. Lehr, A. W. Frazier, Nature 1965, 196, 1050.

[13] N. J. Crane, V. Popescu, M. D. Morris, P. Steenhuis, M. A. Ignelzi Jr., Bone 2006, 39, 434.

[14] O. Suzuki, Acta Biomater. 2010, 6, 3379.

[15] M. Kumar, J. Xie, K. Chittur, C. Riley, Biomaterials 1999, 20, 1389.

[16] M. S. Djosic, V. B. Miskovic-Stankovic, Z. M. Kacarevic-Popovic, B. M. Jokic, N. Bibic, M. Mitric, S. K. Milonjic, R. Jancic-Heinemann, J. Stojanovic, Colloid Surf. A 2009, 341, 110.

[17] Y. Liu, J. P. Li, E. B. Hunziker, K. de Groot, Philos. Trans. A Math Phys. Eng. Sci. 2006, 364, 233.

[18] W. M. M. Heijnen, P. Hartman, J. Cryst. Growth 1991, 108, 290.

[19] H. E. Lundager Madsen, G. Thorvardarson, J. Cryst. Growth 1984, 66, 369.

[20] T. Toshima, R. Hamai, M. Tafu, Y. Takemura, S. Fujita, T. Chohji, S. Tanda, S. Li, G. W. Qin, J. Asian Ceram. Soc. 2014, 2, 52.

[21] K. D. Daskalakis, G. H. Nancollas, in Mineral Scale Formation and Inhibition (Ed.: Z. Amjad), Springer Science + Business Media, New York 1995, p. 219.

[22] F. Barrere, C. M. van der Valk, R. A. Dalmeijer, C. A. van Blitterswijk, K. de Groot, P. Layrolle, J. Biomed. Mater. Res. Part A 2003, 64, 378.

[23] J. Black, G. Hastings, Eds., Handbook of Biomaterial Properties, Chapman \& Hall, London 1998.

[24] A. M. Barradas, V. Monticone, M. Hulsman, C. Danoux, H. Fernandes, Z. T. Birgani, F. Barrere-de Groot, H. Yuan, M. Reinders, P. Habibovic, C. van Blitterswijk, J. de Boer, Integr. Biol. 2013, 5, 920.

[25] D. O. Meredith, L. Eschbach, M. O. Riehle, A. S. Curtis, R. G. Richards, J. Orthop. Res. 2007, 25, 1523.

[26] Y. Liu, R. Shelton, U. Gbureck, J. Barralet, J. Biomed. Mater. Res. Part A 2009, 90, 972.

[27] T. Anada, T. Kumagai, Y. Honda, T. Masuda, R. Kamijo, S. Kamakura, N. Yoshihara, T. Kuriyagawa, H. Shimauchi, O. Suzuki, Tissue Engineering. Part A 2008, 14, 965.

[28] A. M. Barradas, H. A. Fernandes, N. Groen, Y. C. Chai, J. Schrooten, J. van de Peppel, J. P. van Leeuwen, C. A. van Blitterswijk, J. de Boer, Biomaterials 2012, 33, 3205.

[29] E. E. Golub, G. Harrison, A. G. Taylor, S. Camper, I. M. Shapiro, Bone Miner. 1992, 17, 273.

[30] W. C. O'Neill, Circ. Res. 2006, 99, e2.

[31] Z. T. Birgani, C. A. van Blitterswijk, P. Habibovic, J. Mater. Sci. Mater. Med. 2016, 27, 54.

[32] S. C. Mendes, J. M. Tibbe, M. Veenhof, S. K. Both, F. C. Oner, C. van Blitterswijk, J. D. de Bruijn, J. Mater. Sci. Mater. Med. 2004, $15,1123$.

[33] V. Rosen, Cytokine Growth Factor Rev. 2009, 20, 475.

[34] H. I. Roach, Cell Biol. Int. 1994, 18, 617.

[35] H. Newesely, Monatsh. Chem. 1960, 91, 1020.

[36] N. Doebelin, R. Kleeberg, J. Appl. Crystallogr. 2015, 48, 1573.

[37] J. Bergmann, P. Friedel, R. Kleeberg, Comm. Powder Diffract. (IUCr) 1998, 20, 5.

[38] N. A. Curry, D. W. Jones, J. Chem. Soc. A: Inorg. Phys. Theor. 1971, 3725.

[39] B. Dickens, J. S. Bowen, W. E. Brown, Acta Crystallogr. 1971, B28, 797.

[40] M. Mathew, W. E. Brown, L. W. Schroeder, B. Dickens, J. Crystallogr. Spectrosc. Res. 1988, 18, 235.

[41] S. K. Both, A. J. C. Van der Muijsenberg, C. A. Van Blitterswijk, J. De Boer, J. D. De Bruijn, Tissue Eng. 2007, 13, 3.

[42] H. Fernandes, A. Mentink, R. Bank, R. Stoop, C. van Blitterswijk, J. de Boer, Tissue Eng. Pt A 2010, 16, 1693. 